\title{
Community Perception Towards Tourism Development in the Indian Sundarbans: Case Study of Jharkhali Island
}

\author{
Soumik Sarkar ${ }^{1}$ \\ ${ }^{1} \mathrm{PhD}$ Scholar, \\ School of Oceanographic Studies, \\ Jadavpur University,
}

\author{
Suchandra Bardhan ${ }^{2}$ \\ ${ }^{2}$ Professor, \\ Department of Architecture, \\ Jadavpur University
}

\author{
Pranabes Sanyal $^{3}$ \\ ${ }^{3}$ Guest Faculty, \\ School of Oceanographic Studies, \\ Jadavpur University
}

\begin{abstract}
The Indian Sundarban Biosphere Reserve comprises of an area of $9630 \mathrm{~km}^{2}$.Out of this about $5000 \mathrm{~km}^{2}$ is reclaimed Sundarbans and home to about 4.5 million people. Limitations in agriculture and irrigation facilities have pushed a majority of the population to extreme poverty and also paving the way for tourism development in certain places, that is believed to be supportive of local livelihood. Studies have reported local involvement in the supply of food/ raw materials, organizing inter-island boat trips, acting as tourist guides, selling of non-wood forest products (NWFP) etc. These direct and indirect engagements of the local community with the growing tourism in the region have reaped financial benefits. However, unregulated tourism is also known to have potential negative impacts on the environment and social fabric. This paper attempts to report the results of a research study on the response of its inhabitants towards the growth of tourism in the island of Jharkhali in the Indian Sundarbans. In the process, it introduces the demographic profile of the region, maps the growth of tourism in the island in terms of the hospitality sector and how local people perceive this growth in the context of their employment opportunities, livelihood options and rising income levels. Even though mixed responses were received during the study, majority opinion was found to be largely favourable towards tourism.
\end{abstract}

Keywords: Community, perception,response, tourism, livelihood

\section{INTRODUCTION}

According to Dalton et al. (2001) notion of community tend to fall within two major classifications. One a territorial conception of community based on geographic location and the other, relational conception of community based on social network relationships.The operational definition of "community" (Chaskin et al., 2001) is a geographical area that assumes a commonality of circumstances and identity among its people and contains functional units for the delivery of goods and services. Community based ecotourism has always advocated the involvement of the local communities in the development initiatives as they are the most affected group during the conservation process (Rajasenan et al., 2012). The impacts of tourism can be sorted into several categories, the most common ones are; economic, environmental and sociocultural impacts (Cook, Yale and Marqua, 2006). According to Telfer \& Shrpley (2008) there is a wide range of perspectives that can be taken on local communities in the context of tourism development.It is known that local people or these communities directly or indirectly depend on tourism industry for their livelihood.

In tourism sector, an emphasis on community studies developed with the concept of ecotourism that linked visitation to natural areas with local well-being to meet ecological conservation goals. This is reflected in the definition of ecotourism by The International Ecotourism Society (TIES) in 1990 that defined it as 'responsible travel to natural areas that conserves the environment and improves the we1l-being of local people'. This is in perfect tune with the sustainable development conceptpresented by World Commission on Environment and Development (WCED) in 1987 that identified social, economic and environment as the three pillars of sustainability. In the same lines, 'Ecotourism and Sustainable Development: Who Owns Paradise?' (1999) stresses that ecotourism should, among other things, 'directly benefit the economic development and political empowerment of local communities and fosters respect for different cultures and for human rights.' In this context, this paper discusses and presents the results of a study carried out in Jharkhali, an island village in the Indian Sundarbans that aimed to understand the perception of the local villagers to tourism development in the island and the economic benefits derived by them from this sector, keeping in mind that this tourism may not qualify as ecotourism.Beginning with a brief introduction of the region, the paper presentsthe demographic profile of the local community, tracks the growth of tourism in the island through the growth in the hospitality sector and finally, the perception ofthe local people through their direct and indirect engagement with the local tourism industry and if that has resulted in increased economic benefits for them. The study has 
sourced the required information from both primary surveys and secondary literature sources as explained later. The primary surveys were carried out through a structured questionnaire and respondents belonged to the two broad groups- villagers as beneficiaries and thetourism hospitality sector representatives.

\section{STUDY AREA}

The Indian Sundarbans along-with its Bangladesh counterpart are the single largest mangrove chunk of the world, spread within the latitudes $21^{\circ} 30^{\prime} \mathrm{N}-22^{\circ} 40^{\prime} \mathrm{N}$ and longitudes between $88^{\circ} 05^{\prime} \mathrm{E}-89^{\circ} 55^{\prime} \mathrm{E}$ (Curtis, 1933). The Indian Sundarbans forest spreads over the 24Parganas (South) \& 24-Parganas (North) districts having a total area of $4260 \mathrm{~km}^{2}$. It is a part of the Sundarbans Biosphere Reserve, which has been listed as a World Heritage Site since 1984. The total area of the Sundarbans Biosphere Reserve is $9360 \mathrm{~km}^{2}$ (South 24 Parganas Human development Report, 2009, Govt. of West Bengal). This mangrove zone is the habitat of rich bio-diversity with unique interesting flora and fauna and is very potent for its renewable natural resources. The mangrove forest protects the coastal West Bengal from frequent tidal flooding, surges and cyclonic thrust, which very often originate and get concentrated in the Bay of Bengal. Sundarban got its governmental recognition in the year 1830, when James Princep demarcated the northern limit. At that time William Dampier was the commissioner of the Sundarban
Commissionerate and Lt. Hodges was the surveyor. Because of their united effort the northern limit of the Sundarbans was marked by Dampier Hodges line (WWF, 2011).It is an active delta with cris-crossing tidal creeks forming a network of islands. These creeks are called 'khal' in the local language and most of the island names in the region bear a testimony to that. Jharkhali Island is one of such islands, which till a few years back had been under mangrove forest cover (Samanta et al., 2012). The shift in landuse started in the 1990.s and continued through the early period of $21^{\text {st }}$ century and has recently seen an upsurge in the tourism activities in certain pockets. This is the reason for selecting Jharkhali Island for the current study.

Jharkhali: Jharkhali Island is located under Basanti Block of South 24 Parganas district in West Bengal, as shown in the figure. This Island is considered as mid estuarine region and is situated at the heart of the Sundarban Biosphere Reserve. It is located at a distance of about $115 \mathrm{~km}$. from Kolkata. Jharkhali is the entry point of Sundarban and it can be reached from South of Kolkata via Baruipur Canning road. One watch tower, Tiger rescue center, Butterfly garden, Mangrove Park and general scenic beauty are the main tourist attractions of the Jharkhali Island.With rivers Bidyadhari on the east, Matla on the west and Herobhanga on the south, the village named Lot No. 126 is the main tourism hub along-with its neighbouring village named Garanbose.

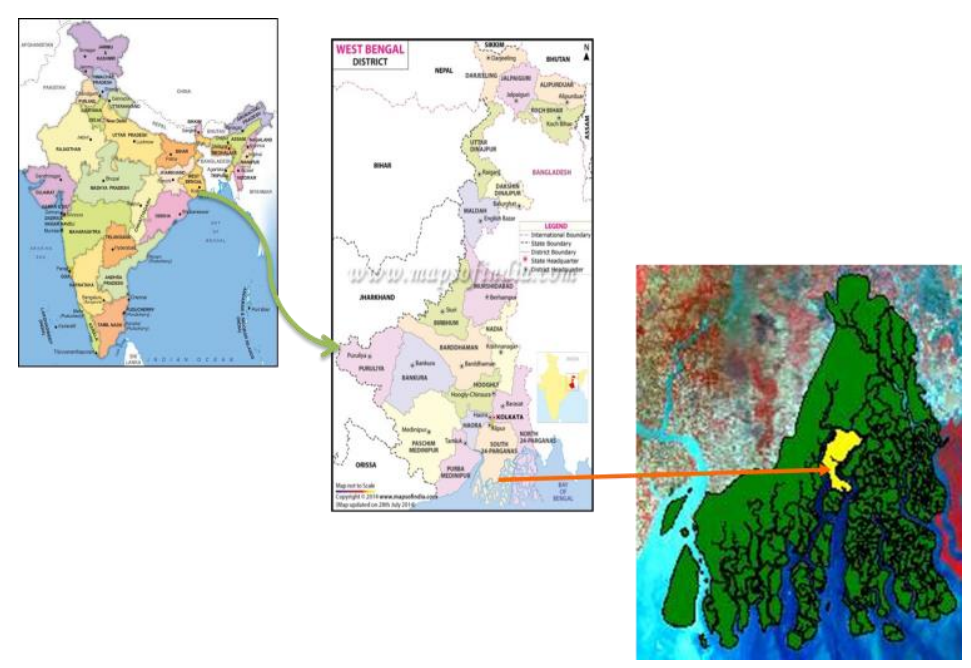

Plate 1: Jharkhali Island location 


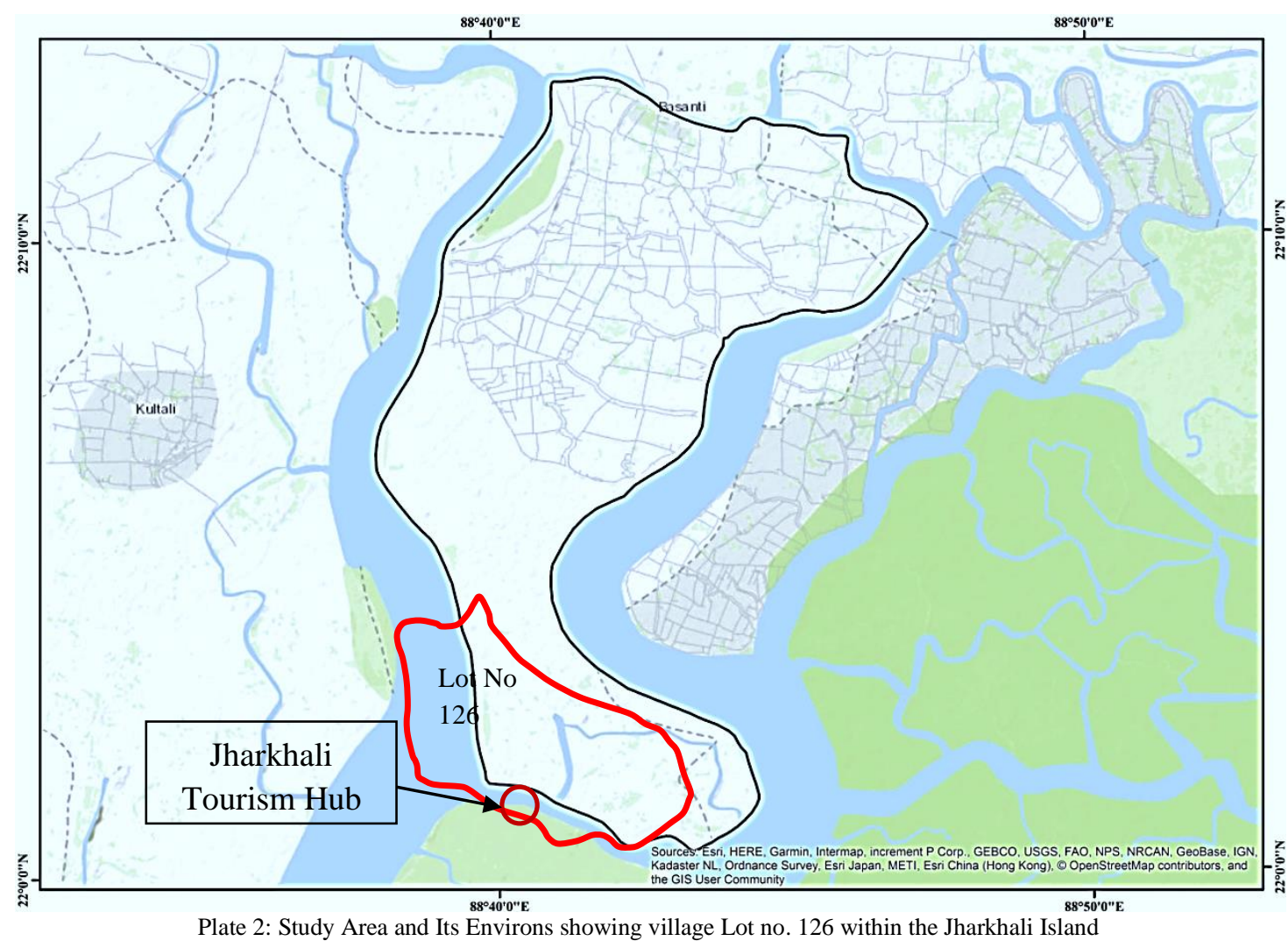

\section{MATERIAL AND METHODS}

Since the study focused on community response and perception of tourism, itwas important to meet the local people in person and seek their views. This formed the much needed primary data and information base. This field survey was conducted through a pre-designed structured questionnaire and one to one interview process. Separate survey questionnaires were prepared to collect primary information from households and hotels of the Lot no. 126 village. Secondary data were collected from Survey of India Topographical maps, Digital Satellite imagery and 2011 census data.

The landuse map has been prepared from digital satellite image data of Landsat TM (year 2014, spatial resolution 30 meter, Season - January) acquired from National Remote Sensing Centre, Hyderabad, with field verifications. Survey of India's Topographical Map was compared with the satellite data.

The primary survey on tourism activity was conducted using survey data sheet format following the scientific methods. Two types of data sheetsfor house-holders interview and hotel survey questionnairewere prepared for collecting the primary data. The household survey data sheet was prepared to collect basic information on family members, level of education, source of income or type of occupations and how they are involvedwith the local tourism sector.

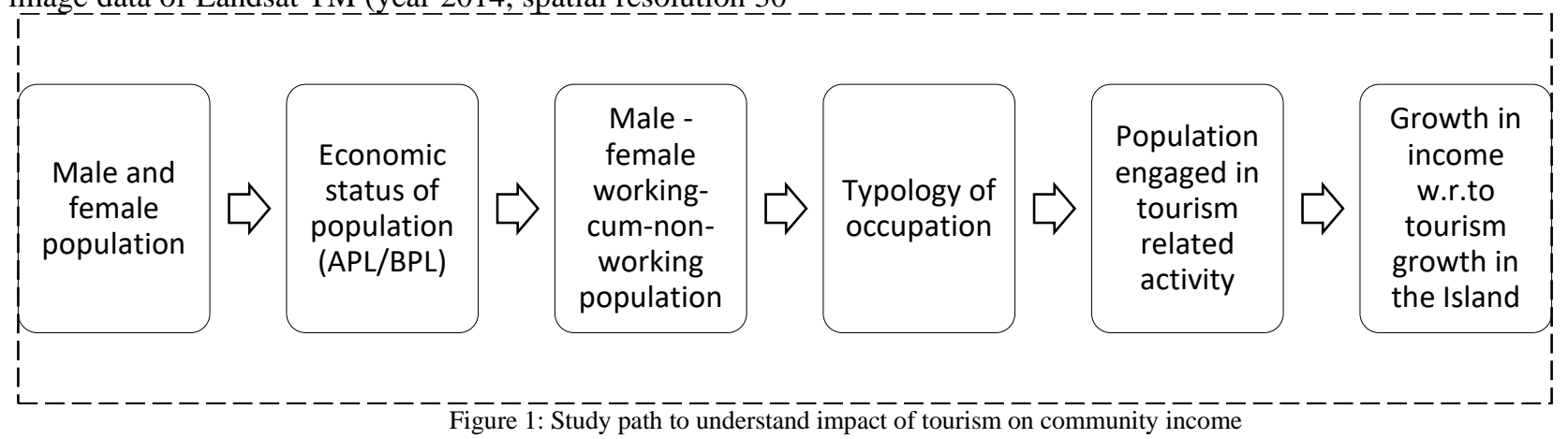

Similarly, the hotel survey data sheet was prepared to collect basic information on hotel facilities, services, accommodation, employees, number of tourists visiting the hotel, annual income of the hotel and awareness of the environment in the hotel. Global Positioning System (GPS) device was used to locate the exact positions of the hotels and local houses. After distributing surveying questionnaires (households and hotels) in the study area, completed answer sheets were received for 50 numbers of households selected randomly and all the 13 numbers of hotels that run business in the village. All these survey data, household data and hotel survey data set were entered in excel sheet for analysis. 




\section{RESULTS AND DISCUSSIONS}

Demographicprofile of local population: As mentioned earlier, Lot No. 126 is the main tourism hub of Jharkhali Island and the household survey was conducted in this area. The total number of population is 15695 at village Lot No. 126 according to census 2011. Villagers are mostly engaged in primary economic activities like agriculture labour, daily labour, fishing, honey collection, wood collection etc. Out of the 50 households, the number of

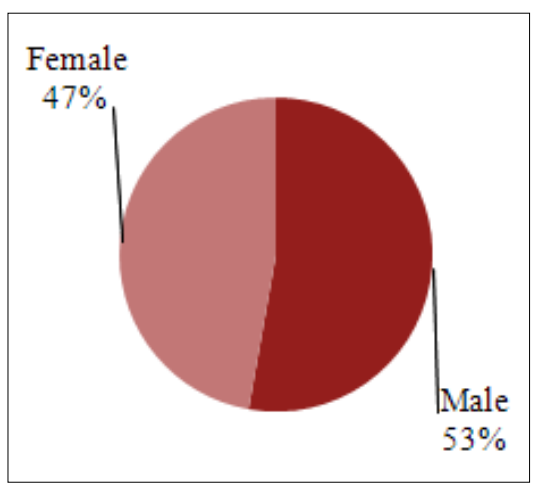

Figure 3: Percentage of Male-Female population male population was found to be 132 and female population 118. Fig. 3 shows the percentage of male-female population, whereas fig. 4 shows the percentage of age-sex graph of the surveyed population. Number of males outweighs the number of females. Findings reveal that most males and females of the village fall within the age bracket of 15-34 years. It is seen that people of employable age dominate the village population.

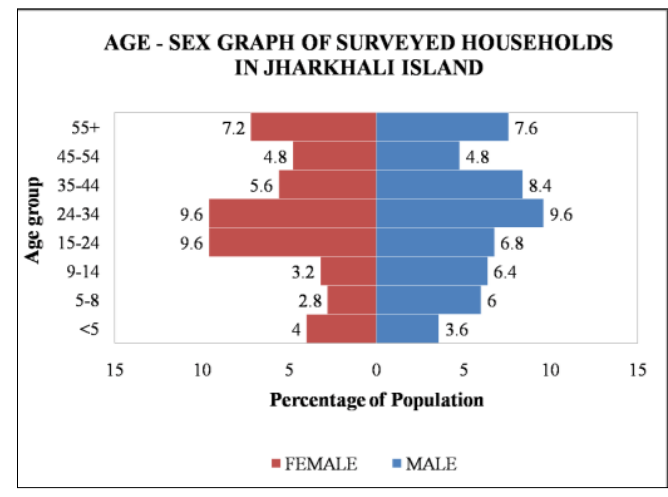

Figure 4: Population Pyramid

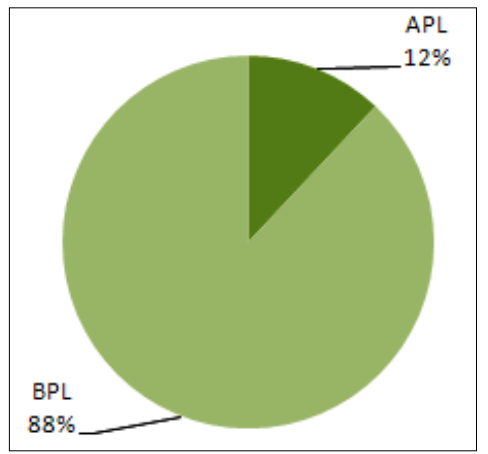

Figure 5: Economic status of surveyed population

The survey aiming to find out the socio-economic structure of the local village community has been assessed in terms of their living standards, educational status and income structure. In terms of income, it was found that 44 families remain Below Poverty Line or BPL $(88 \%)$ and only 6 families belong to Above Poverty Line or APL (12\%), as indicated in fig.5. Internationally, the Below Poverty Line scenario includes those earning 1.90 USD /day in 2015 (World Bank Group, 2016). However, in this study the
APL \& BPL categories were determined based onwhat was given in their Ration Card, under the National Food Security Act.

As discussed before, an analysis of fig. 4 shows that about $37 \%$ women (i.e. $78 \%$ of the total women population) and $37 \%$ (i.e. $70 \%$ of total male population) in the surveyed group are above the age of 15 and therefore, belong to the employable age. However, it was found that only $1.2 \%$ women and $26 \%$ of men are engaged in income generating 
work, as given in fig.7 while fig.6 gives the overall percentage of working and non-working population, whereby it is seen that only $27 \%$ of total population,

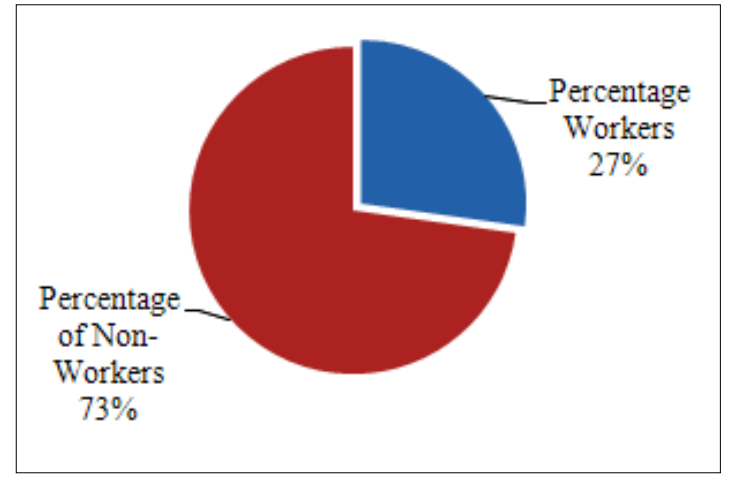

Figure 6: Worker \& Non-Worker Population including both male and female, are actually working while the rest are all non-workers.



Figure 7: Sex-wise Working status of Population

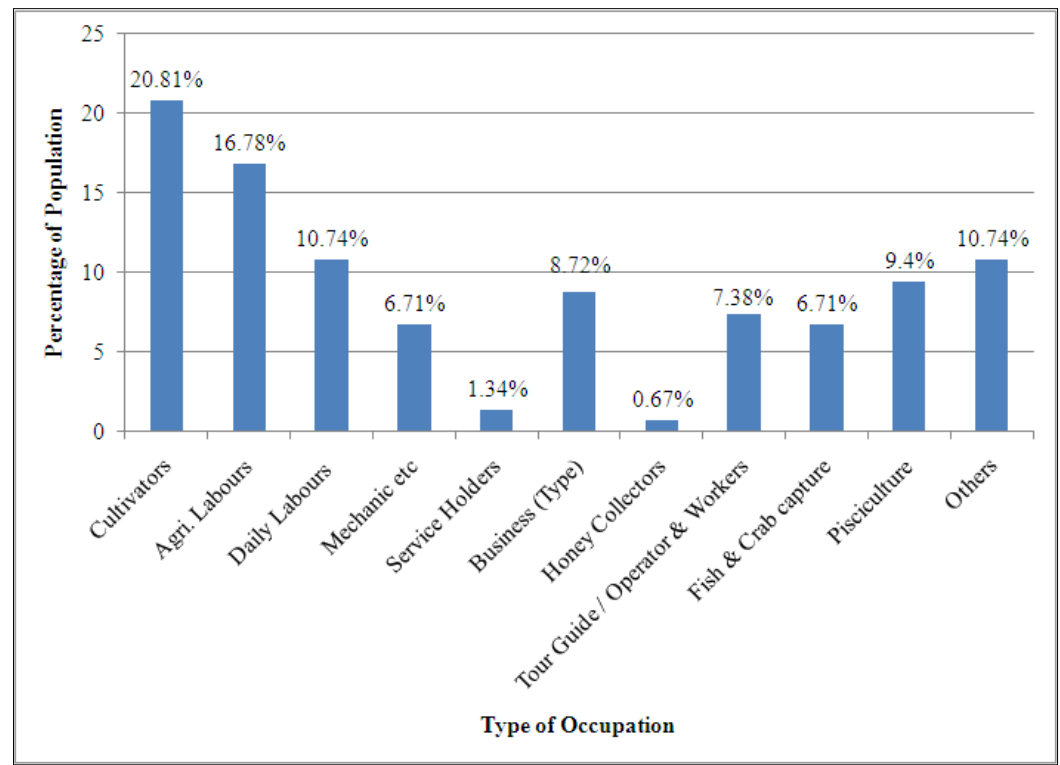

Figure 8: Occupation status of surveyed population

Analysis was carried out about the monthly income status, earnings from tourism industry, percentage of population, their direct/indirect involvement in tourism industry and how long they are involved in this sector at Jharkhali Island. The fig. 8 shows the occupation type of local people in Jharkhali Island. On the basis of collection of the primary data on field and their further analysis reveals that 56 people $(38 \%)$ are cultivators and agricultural labour. Only 16 people $(10.74 \%)$ are daily wage earners. The graph shows that most working populations are involved in primary economic activities. Eleven people (7.38\%) are directly involved in tourism industry, such as tour guides, tour operators, cooks and general workers. It is interesting to note that tourism in this near coastal village is mostly seasonal and remains active for six months in a yearOctober to March, peaking up in December-January. This is why the villagers are engaged in multifarious activities to sustain themselves for the rest of the year. Twenty five people $(16.78 \%)$ are indirectly involved in tourism industry, in occupations such as honey collection, fish \& crab capture and pisciculture. Small businesses like tea/ snacks/ cigarette/ cold drinks stalls are also there, catering to the tourists. According to the result, local people and communities are both directly and indirectly involved in the tourism industry. 


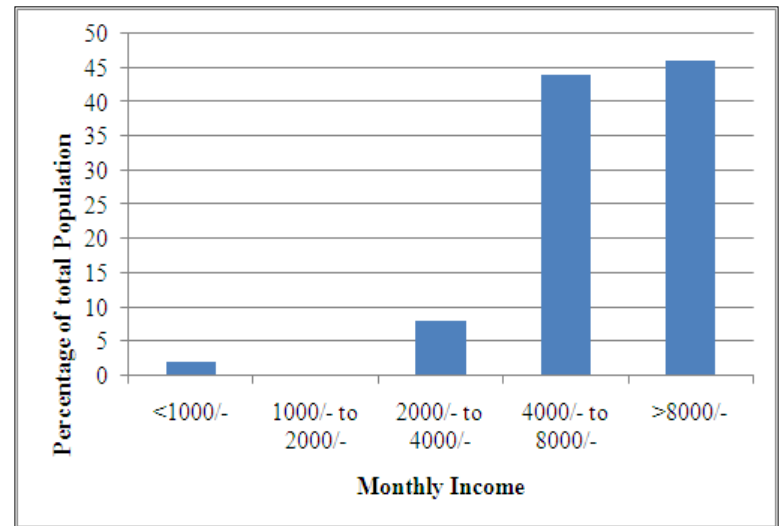

Figure 9: Monthly Income Status of villagers

The evaluation of income brings out the overall picture of the financial status of the study area. The fig. 9 reveals that a large part of the working population earns above Rs. 8000 (i.e. 114.90 USD at current conversion rate of May 2019) per month. A very small proportion of the villagers earn within the income range below Rs. 1000 per month which is similar to another handful of villagers belonging to Rs. 4000-8000 earning group. Comparison between fig. 9 and fig. 10 shows that at the lowest, $45.45 \%$ persons earn $21 \%$ to $40 \%$ of their total monthly income in tourism industry while $22.73 \%$ of working population earns $61-80 \%$ of their monthly income from tourism sector. It is obvious that this $22.73 \%$ are the direct financial beneficiaries of the local tourism industry and thus, receiving its positive economic benefits.

\section{Growth of Tourism in Jharkhali Island}

As mentioned before, the village Lot no. 126 located at the southernmost end of the Jharkhali Island houses the main tourist hub and hence, has been selected for this study. The map (Plate 3) shows the location of the surveyed

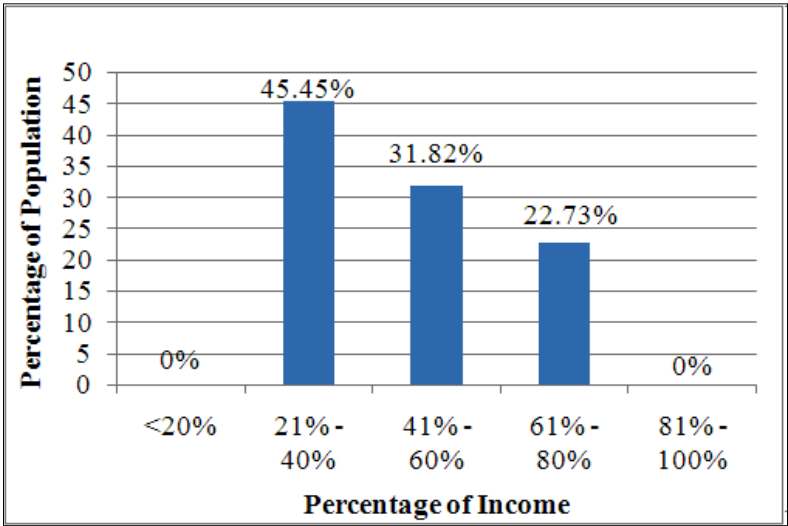

Figure 10: Income generated from tourism industry

households and hotels in the village using GPS device. The red dots indicate the exact geographical locations of the surveyed houses and yellow dots show the exact location of all the 13 hotels in the Jharkhali tourism hub areas. The major part of the study area is under agricultural use with some settlements with vegetations that are concentrated along both sides of the roads in more or less linear patterns. Some natural and man-made water bodies are found scattered within this fabric. A small part of dense forest also exists in the north-western part of the Island. Maximum numbers of aquaculture farm can be found in the northern part and southern end of the study area. Close to the River Herobhanga on the south, the only mangrove nursery is one of the main tourist attractions. The State Govt. tourist hub located near the river is under development, which when finished, is expected to boost tourism further. The extent of the tourism spread in the region vis-à-vis the study area is marked by the red circle denoting an area of $7.56 \mathrm{sq}$. km with a radius of $1.56 \mathrm{~km}$ and the yellow circle having an area of $4.12 \mathrm{sq}$. $\mathrm{km}$ with a radius of $1.14 \mathrm{~km}$ respectively.
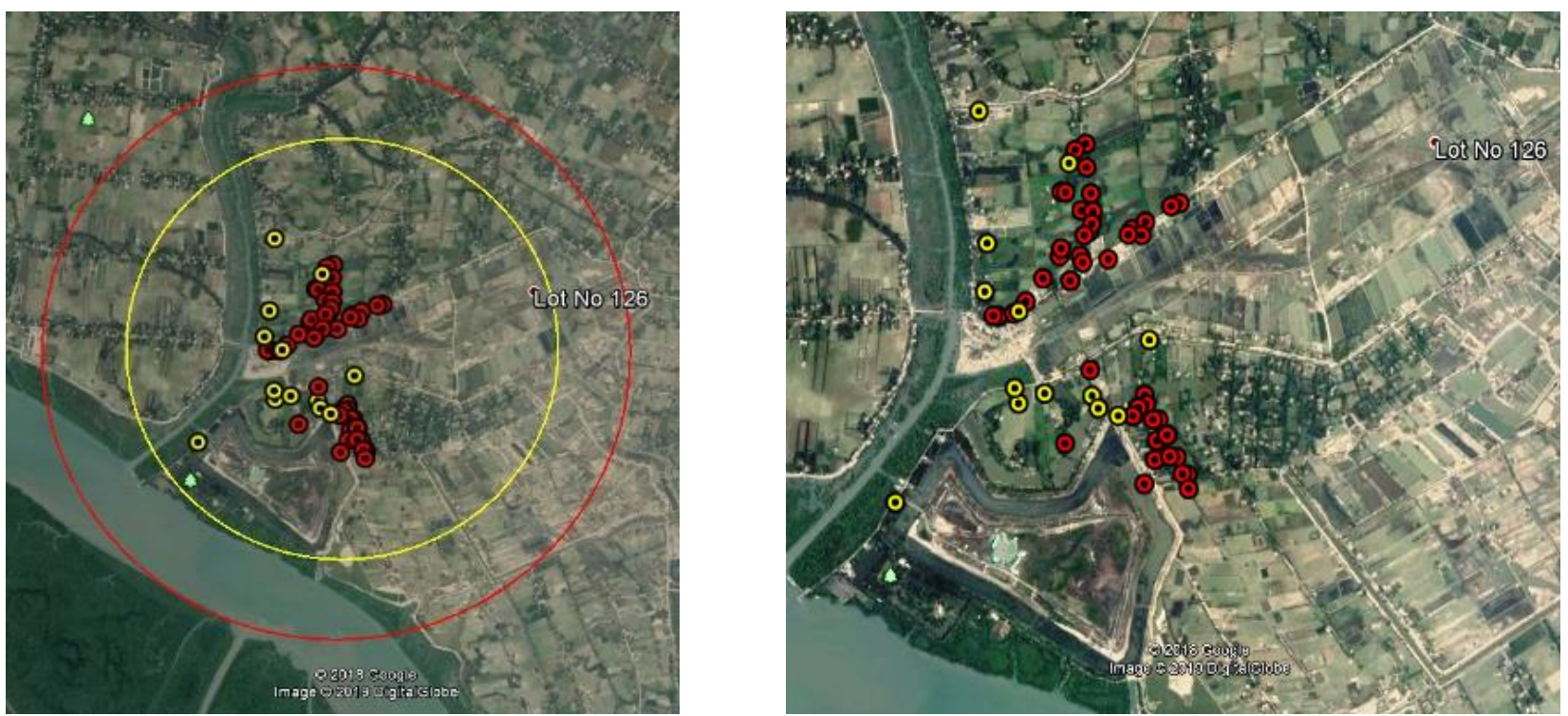

Plate: 3 Field survey locations using GPS device 
Basic information on the hotels availed through the primary survey are tabulated in Table 1 showing the year of establishment of the hotels in the Jharkhali Island. For the sake of privacy, the hotels have been numbered as $\mathrm{H} 1$, $\mathrm{H} 2$....H13. The government lodging facility named $\mathrm{H} 1$ is the oldest hotel in this region, which was established in the year 1983 by the State Tourism Department. The second hotel H2 was established through private initiative in 2005 and thereafter eleven other hotels were established in this region, out of which six were established in the year 2013 and three were established in the year 2014. It is also evident from this tablethat the total number of hotels made before 2010 had a total bed capacity of 79 , while144 more beds were added in just seven years till the study was conducted.Currently, the total bed capacity in this region stands at 223 on the basis of primary data processing.

The Table shows that for 22 years, the Govt. lodging facility with only six beds was the sole representative of hospitality sector in the tourist map of the region. In 2005 and 2008, 73 new beds were added, taking the total bed accommodation capacity to 79 . This was probably due to a new found corporate interest in developing the whole of Indian Sundarbans as an ecotourism destination that was ideated in 2003 and also included Jharkhali in its fold (TOI, 2002), which triggered infrastructure development in the region including improvement in accessibility.

Table 1: Basic information on hotels

\begin{tabular}{|c|c|c|c|c|c|c|c|c|}
\hline Sl No & $\begin{array}{l}\text { Name Of The } \\
\text { Hotel }\end{array}$ & $\begin{array}{c}\text { Establishment } \\
\text { Year }\end{array}$ & $\begin{array}{l}\text { Total built up } \\
\text { Area in sq. } \mathrm{m}\end{array}$ & $\begin{array}{l}\text { Capacity } \\
\text { (Beds) as in } \\
2018\end{array}$ & $\begin{array}{l}\text { Cumulative } \\
\text { beds }\end{array}$ & \begin{tabular}{|c|} 
Built up \\
Area/bed (sq. m)
\end{tabular} & \begin{tabular}{|c|} 
Tariff - \\
Average Per \\
Head per night \\
(Rs.)
\end{tabular} & Ownership \\
\hline & & & A & B & $\sum \mathrm{B}$ & $\mathrm{C}=\mathrm{B} / \mathrm{A}$ & & \\
\hline 1 & H1 & 1983 & 79.37 & 6 & 6 & 13.23 & 400 & $\begin{array}{c}\text { Tourism Dept. Govt. of } \\
\text { WB }\end{array}$ \\
\hline 2 & $\mathrm{H} 2$ & 2005 & 135.06 & 36 & 42 & 3.75 & 450 & Private \\
\hline 3 & $\mathrm{H} 3$ & 2008 & 286.52 & 37 & 79 & 7.74 & 600 & Private \\
\hline 4 & $\mathrm{H} 4$ & 2013 & 96.95 & 25 & 104 & 3.88 & 400 & Private \\
\hline 5 & H5 & 2013 & 227.75 & 16 & 120 & 14.23 & 1000 & Private \\
\hline 6 & H6 & 2013 & 55.20 & 11 & 131 & 5.02 & 400 & Private \\
\hline 7 & $\mathrm{H} 7$ & 2013 & 94.55 & 4 & 135 & 23.64 & 500 & Private \\
\hline 8 & $\mathrm{H} 8$ & 2013 & 161.94 & 6 & 141 & 26.99 & 600 & Private \\
\hline 9 & H9 & 2013 & 258.7 & 16 & 157 & 16.17 & 900 & Private \\
\hline 10 & H10 & 2014 & 42.35 & 10 & 167 & 4.24 & 600 & Private \\
\hline 11 & H11 & 2014 & 73.79 & 8 & 175 & 9.22 & 500 & Private \\
\hline 12 & $\mathrm{H} 12$ & 2014 & 157.70 & 36 & 211 & 4.38 & 650 & Private \\
\hline 13 & $\mathrm{H} 13$ & 2017 & 74.79 & 12 & 223 & 6.23 & 850 & Private \\
\hline & Total & & 1744.67 & 223 & 223 & & & \\
\hline
\end{tabular}

However, the proposal was abandoned subsequently and the elaborate tourism plan fell short of success causing stagnation for the next five years. Meanwhile, a change of government in the state and new pro-tourism policy reflected in the growth of tourism when six hotels were established in the year 2013 itself, doubling the number of beds in the region, as shown in figures 11 and 12 . The steep rise in the number of hotels from 2013 onward is represented in figure 12 .

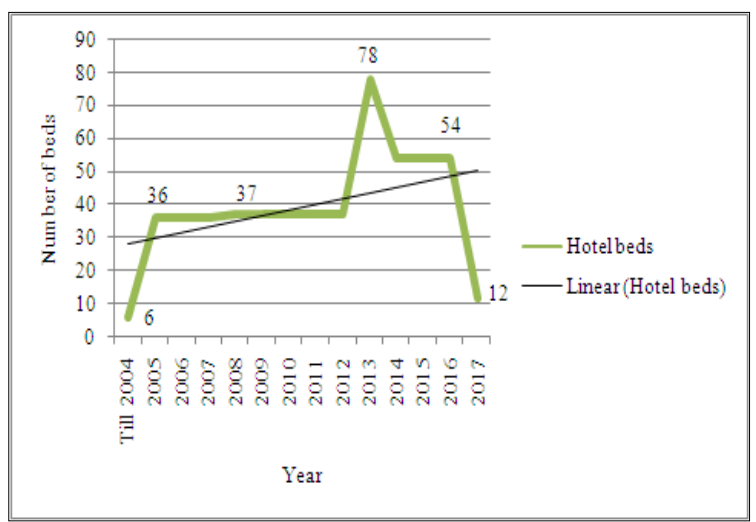

Figure 11: Year-wise increase in no. of hotels

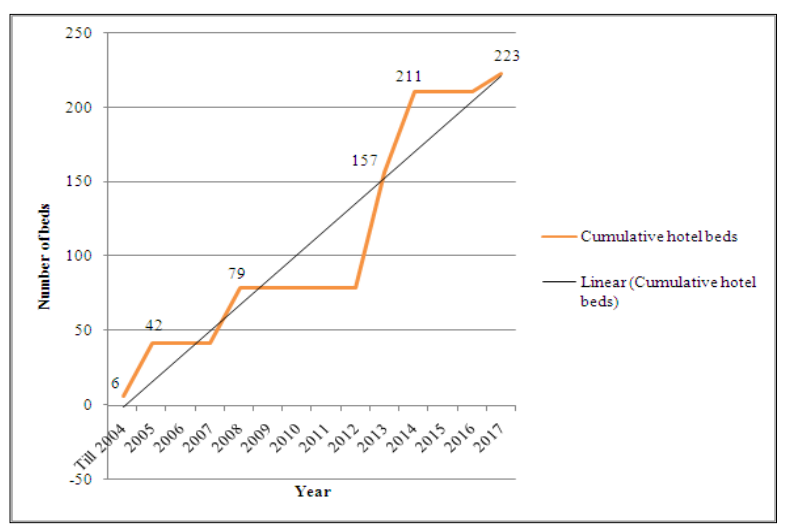

Figure 12: Cumulative rise in no. of beds from 2004-2017 
However, hospitality sector is not just about number of accommodation and bed capacity; it has a lot to do with the quality of the space and services offered to the tourists by the particular hotel. In order to check this, the paper first tried to see the amount of space available per bed in the hotels and the room tariff charged by them. These are overlaid and presented in the figure11. It shows that other than the government lodging (H1), only two other hotels are charging lower compared to the others while providing more space per bed. The newer hotels are evidently more optimizing on space while charging fairly high, presumably with quality space and service.

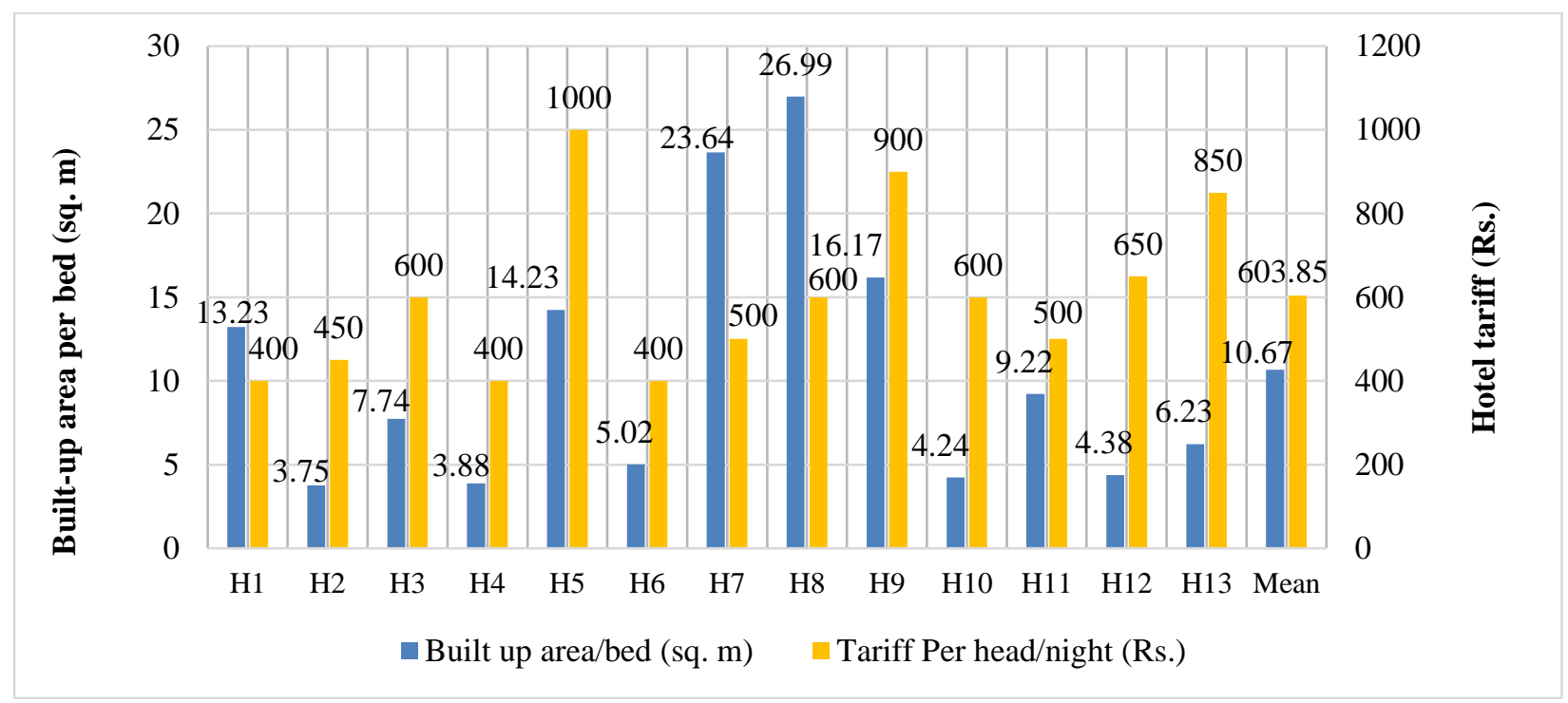

Figure 13: Comparison between hotel spaces vis-a-vis room charges/night per tourist

The Table 2 shows the economic class of the hotels in the Jharkhali Island based on the hotel tariff. Three types of hotels are available, such as low budget hotel (less than Rs. 400 per bed per night), middle budget (above Rs. 400 and up to Rs. 800 per bed per night) and high budget hotel (above Rs. 800 per bed per night). This Table indicates that the number of hotels in the middle budget is more than the other two classes taken together while the number of beds in the same category is about 1.6 times of that of the other two classes, again taken together. The average built up area per bed for the middle budget category is also commensurate with the tariff.

Table 2: Economic class of the hotel

\begin{tabular}{|l|c|c|c|}
\hline & \multicolumn{3}{|c|}{ Economic class of the hotel } \\
\cline { 2 - 4 } & $\begin{array}{c}\text { Low budget } \\
(<=\text { Rs. 400/-per bed per } \\
\text { night })\end{array}$ & $\begin{array}{c}\text { Middle budget } \\
\text { (Rs. 401/- to Rs. 800/- per bed per night) }\end{array}$ & $\begin{array}{c}\text { High budget } \\
\text { (Above Rs. 800/-per bed per } \\
\text { night })\end{array}$ \\
\hline No. of Hotels & $3 \mathrm{nos}$. & $7 \mathrm{nos}$. & $3 \mathrm{nos}$. \\
\hline Average Built up Area/bed & $7.37 \mathrm{sq} . \mathrm{m} / \mathrm{bed}$ & $11.42 \mathrm{sq} . \mathrm{m} / \mathrm{bed}$ & $12.21 \mathrm{sq} . \mathrm{m} / \mathrm{bed}$ \\
\hline Capacity as in 2018 & $42 \mathrm{beds}$ & $137 \mathrm{beds}$ & 44 beds \\
\hline
\end{tabular}

An assessment of the economic class of the hotel shows that maximum number of hotels lie in the mid-budget category, charging between Rs. 400 to Rs. 800 per bed per night (figure 14). It is clear that this class finds preference with the tourists visiting this region and mostly caters to the middle income group domestic tourists. 


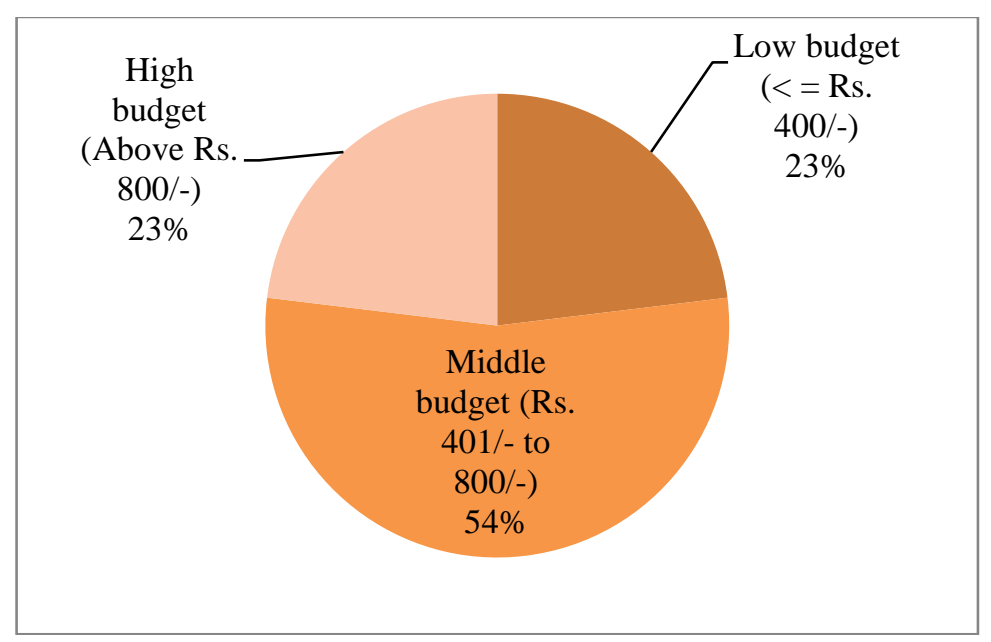

Figure 14: percentage-wise economic class of hotels



Figure 15: Comparison between increase of hotels vis-a-vis tourist foot-fall

Next, the study attempted to check if the increase in hotel is rationally reflected in simultaneous rise in tourist footfall as per data obtained from the hotels. It was found that the tourist population increase is also at par with the growth of the hotels and shows a compatible growth with respect to hospitality infrastructure (figure 15). This upward trend is also corroborated by the profitability of the hotels, as evident from the figure 16 as per the result of the conducted survey. 


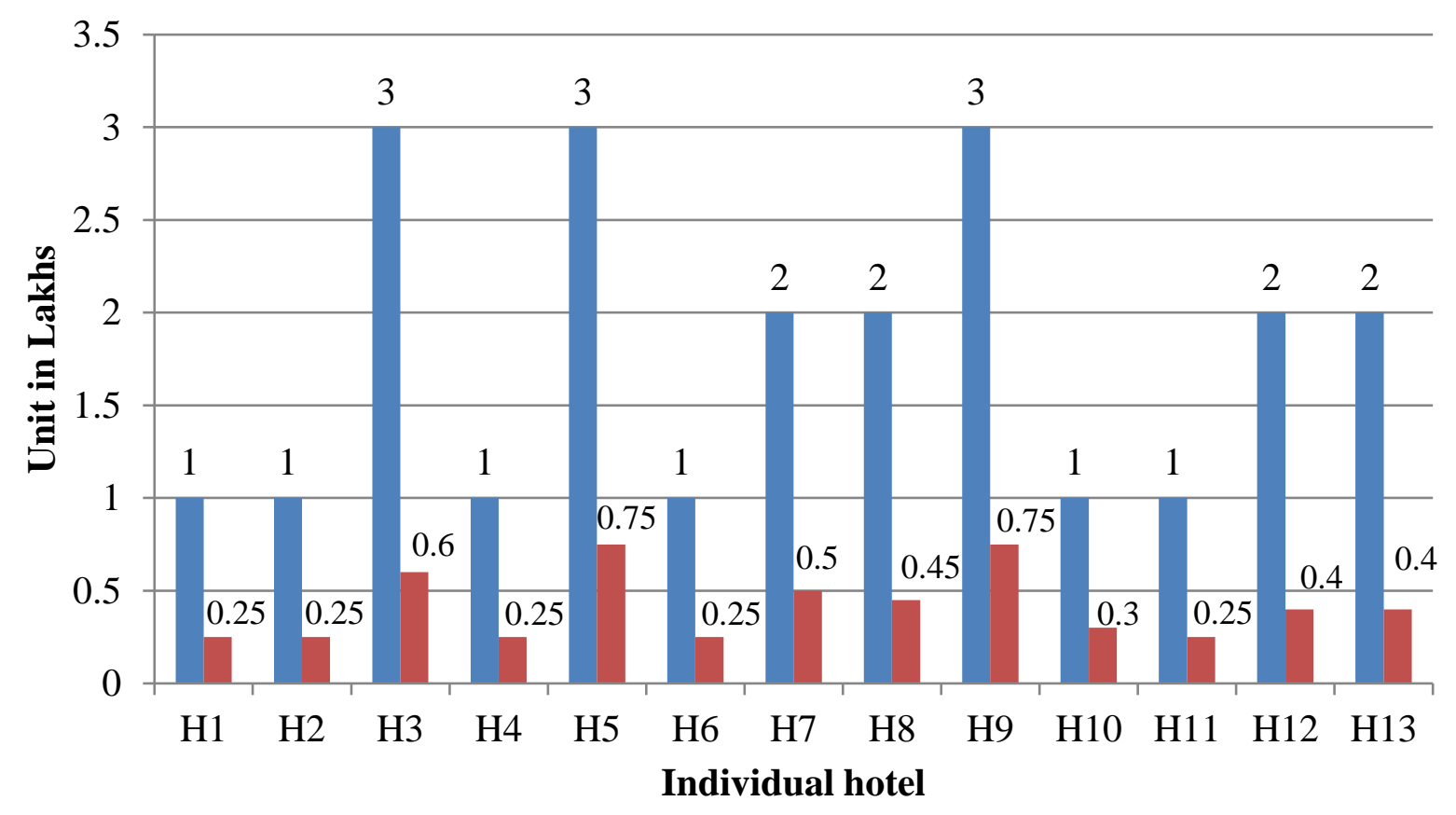

- Average annual income $\quad$ Average annual expenditure

Figure 16: Average Annual Income and Expenditure of hotels

According to the primary field survey information, H3, H5 and $\mathrm{H} 9$ have the highest average annual income of Rs. 3,00,000 (approximately). H7, H8, H12 and $\mathrm{H} 13$ have an average annual income of Rs. 2,00,000 (approx). Others six hotels have the average annual income of not less than one lakh approximately. The corresponding average expenditure of the hotels are also shown simultaneously, which varies between Rs. 0.75 lakh (approx) to Rs. 0.25 lakh approximately. This is due to differing levels of services offered by the hotels.

\section{Community Involvement in Tourism Sector}

In general it was seen that these hotels provide financial benefit to the local people as amajority of the hotel owners and workers are local residents of this region. The survey findings point towards $54 \%$ of local ownership of hotels against $38 \%$ of non-local owners (fig. 17). This means local investment and returns are both generated and retained within the village. It also highlights the fact that local community is taking interest in participating in the process, which gets translated into community entrepreneurship in tourism growth and consequent benefits. The primary survey enquiries revealed the percentage of people engaged directly and indirectly with the tourism sector, which has also enhanced with the rise in the number of hotels in the region, as indicated in figure 17

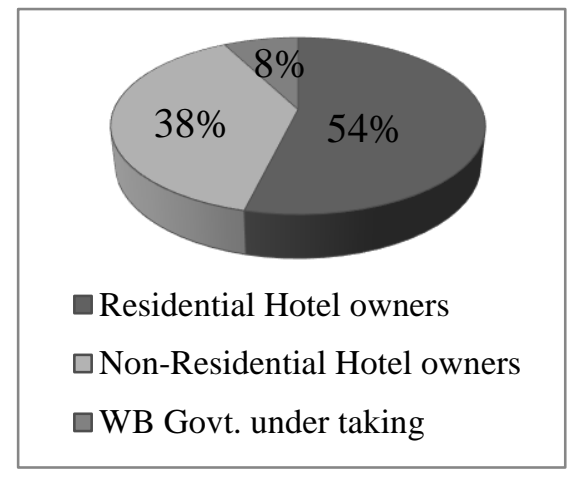

Figure 17: Nature of hotel ownership 


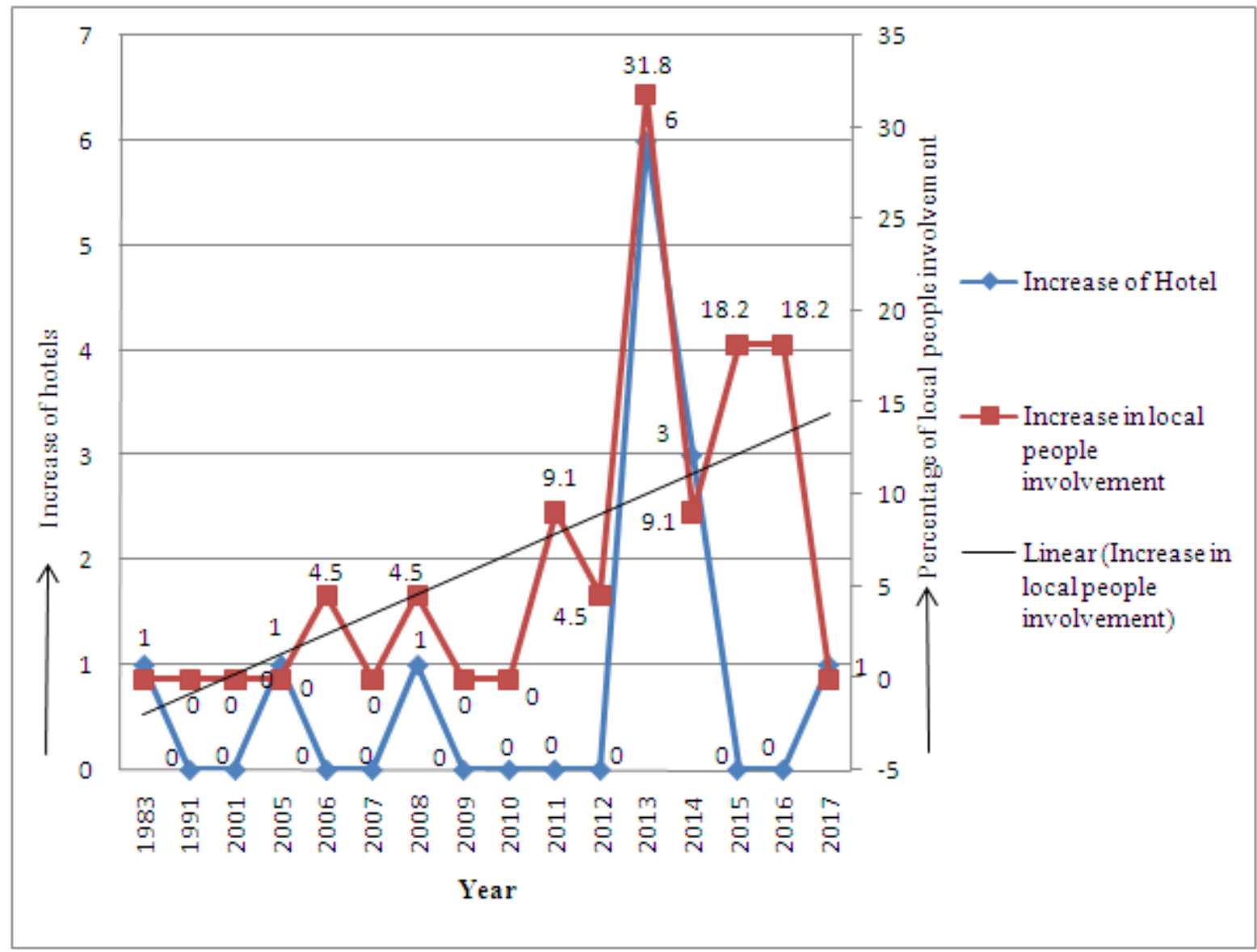

Figure 18: Comparison between increase in number of hotels vis-a-vis local people involvement

Thus, local community inclusion in the tourism business is showing a strong positive trend (fig. 18). The study result further showed the duration of this direct/indirect involvement: $5 \%$ of the populations are engaged for the last 12 years, $32 \%$ of the population for the lastfive years and $18 \%$ of the population for the last two years.
It was also found that $43 \%$ were directly engagedin the hotels while $53 \%$ were into activities that are indirectly related to tourism. The nature of this indirect involvement is given in the following figures 19 and 20:

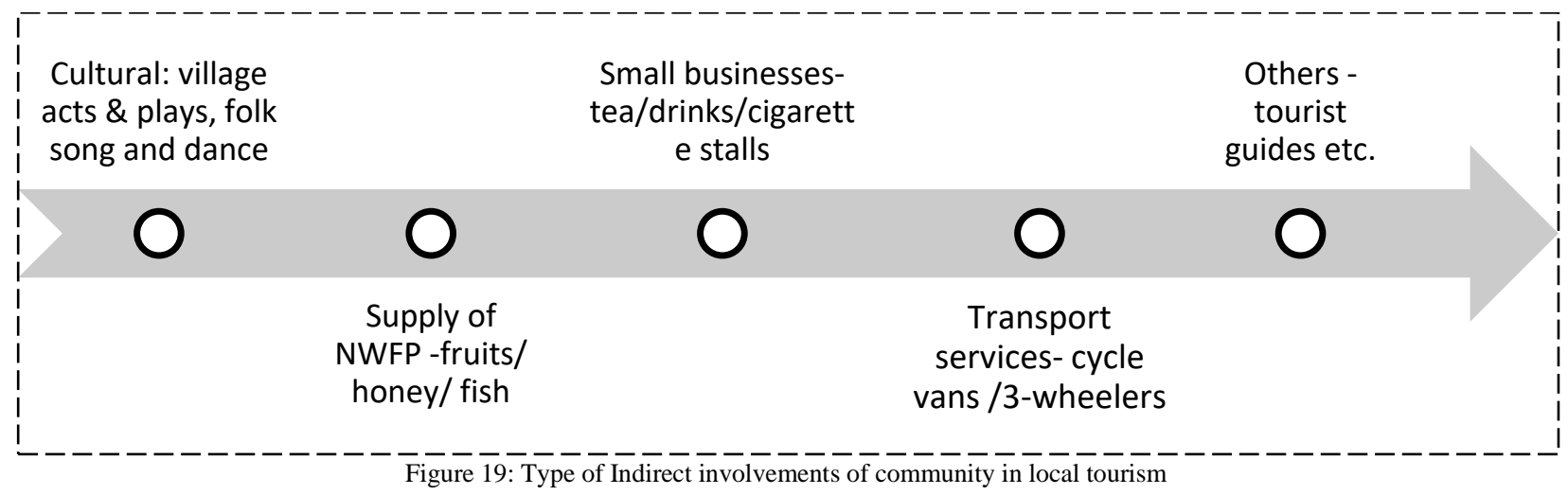

i. Cultural programs include local acts and plays, popularly based on community belief systems and presented as Sitalapala, Bonobibipala, Manashapala, Boulgan, Jhumurnachetc. This is to entertain the tourists in the evening.

ii. Supply and sale of Non Wood Forest Products (NWFP) like fruits \& box-nuts (Bel, Sabeda,
Green Coconut), mangrove products like ChakKeura fruit, forest procured pure honey and local pisciculture products such as Crab, fish etc.

iii. Small businesses include tea stalls and those selling mineral water, cold drinks, snacks and other small Fast-Moving Consumer Goods (FMCG) products. 
iv. Transport services required to ferry tourists locally by three-wheeler services from Jharkhali bus stand to Jharkhali tourism hub parking zone and by cycle vans from Jharkhali parking zone to Jetty ghat or Tiger Rescue Centre.

v. Miscellaneous/ other avenues of involvements that include Tour Guide services, boat operators, cook, car parking monitoring etc.
The percentage distribution of the above activities are indicated in figure 20 whereby it is seen that the major share belongs to sale of Non Wood Forest Products (NWFP) and fruits products taken together as well as by others miscellaneous involvements, both at $38 \%$ followed by transport services at $12 \%$, small businesses at $9 \%$, cultural activities at $3 \%$.

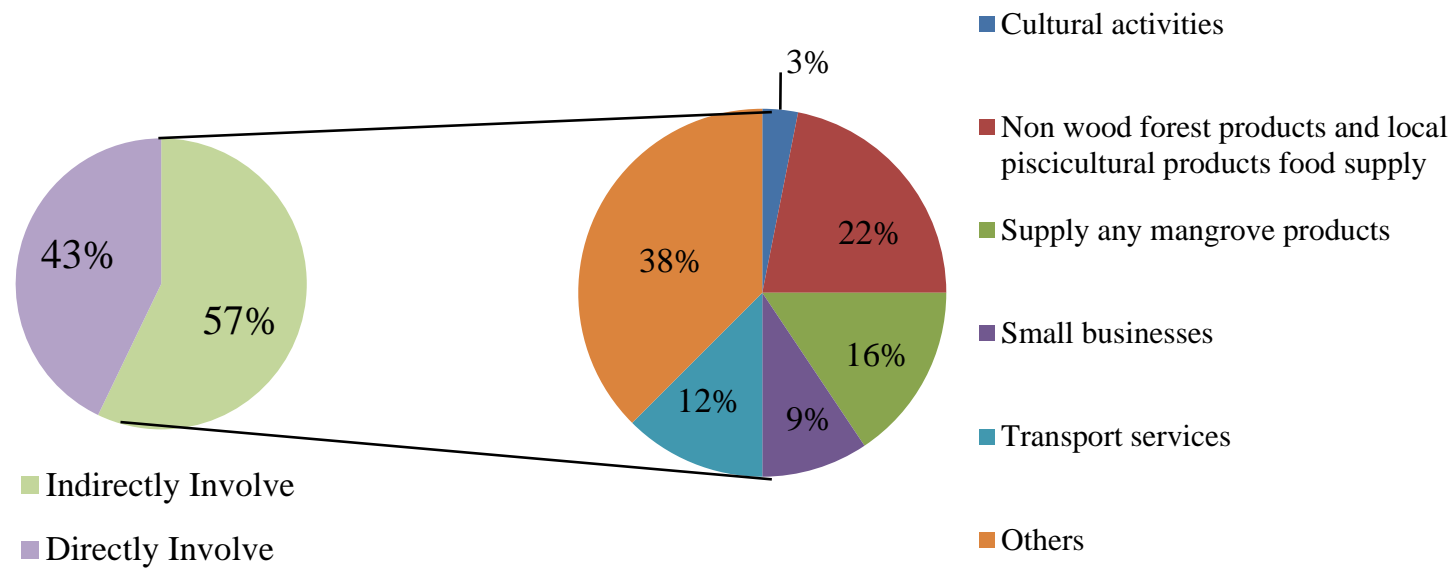

Figure 20: Share and Types of community involvement in tourism sector

\section{Community perception of economic impact of tourism in} the region

Since the concept of home-stay has become popular in many tourist destinations and also preferred by tourists for an authentic local experience of the place and developing a connection with the local people, the primary survey enquired the local community if it was open to such ideas. This would then unlock yet another economic opportunity for the community leading to additional financial gains for them. The results are encouraging with $52 \%$ people opining in favour of home-stays.

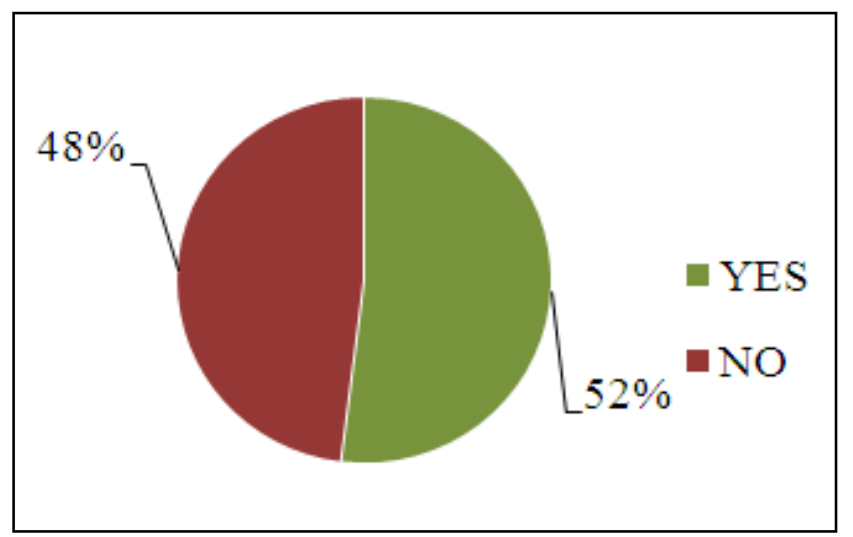

Figure 21: Percentage of interested people to extend their house for home stay tourism 


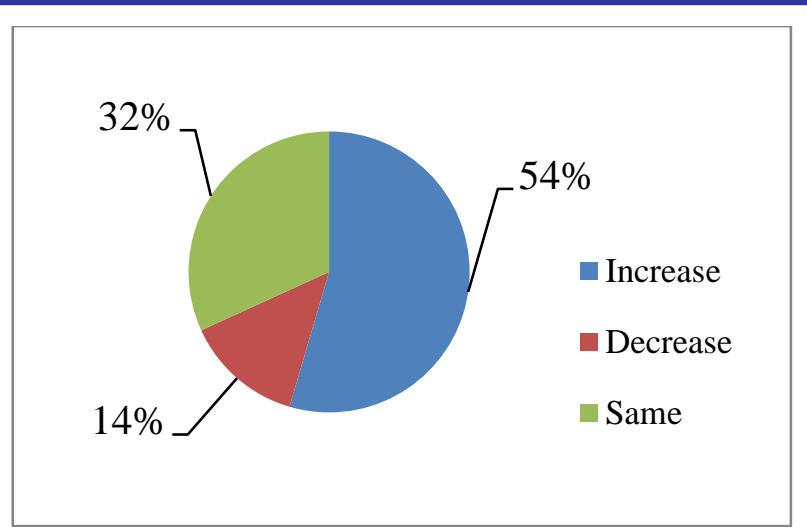

Figure 22: Change in income due to increased tourismactivity in the region

Figure 22 shows the community response to increased income due to tourism development in the region where $54 \%$ of the population gave positive feedback. Only $14 \%$ population responded negatively while $32 \%$ did not perceive any change in their income levels.

\section{Community perceptionofenvironmental impact of tourism in the region}

The survey further attempted to understand how the community perceives its changing environment due to tourism and growing number of tourists invading their space. Here about $41 \%$ of the population shared their environmental concerns on biodiversity and pollution, while $59 \%$ did not see any negative change (figure 23 ). The major concern expressed was in terms of pollution, particularly air pollution as increased tourism would result in rise in vehicular traffic plying between Kolkata and Jharkahli.

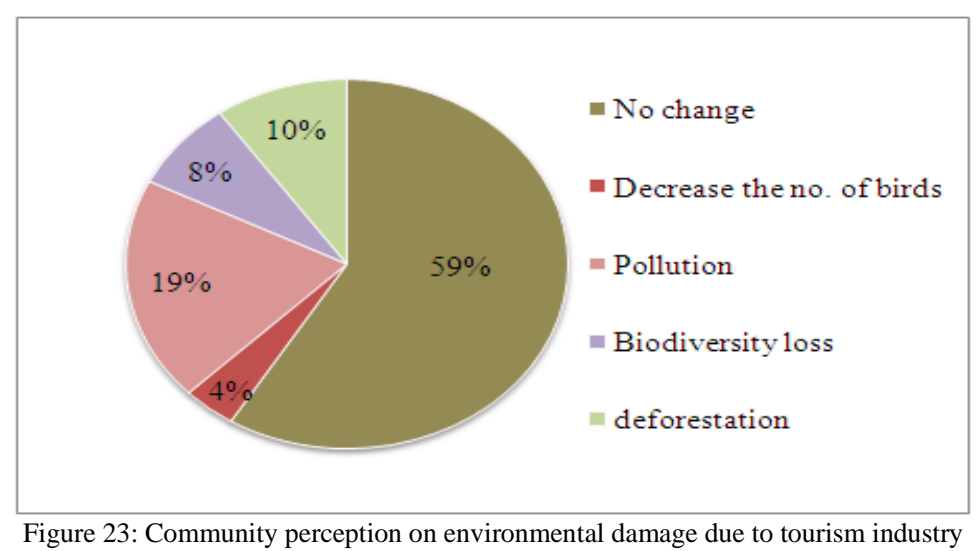

\section{Community perception of social impact of tourism in the} region

Likewise, the survey enquired on the local perception of tourism impact on their rural community and whether they perceive any threat to their way of living, traditions, social customs or belief systems. Qustions were also asked if tourism is affecting their lives negatively or has improved their living standards. The response was again overwhelmingly in favour of tourism barring a small percentage (4-6\%) who felt the other way. The results are given in figures 24 and 25 .

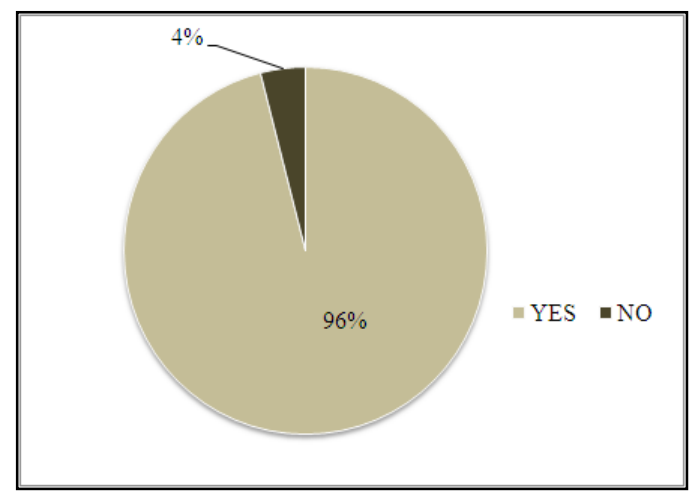

Figure 24: Community perception on positive social impact 


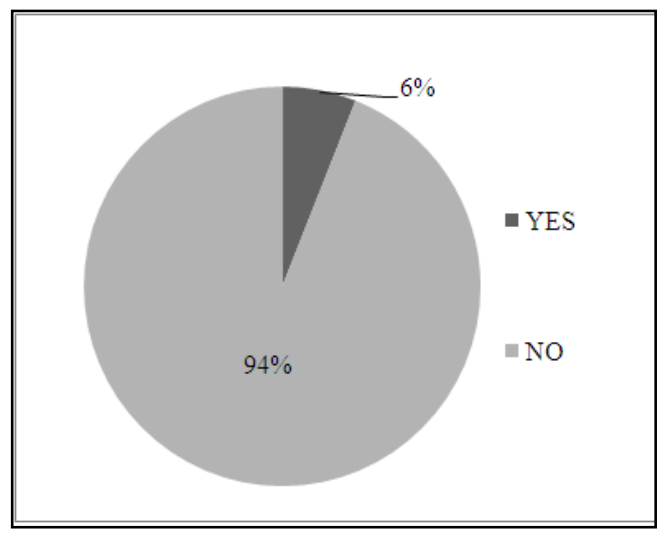

Figure 25: Community perception on negative social impact

\section{CONCLUSION:}

This work has attempted to assess the community response to tourism development in one of the island villages of the Indian Sundarbans that is experiencing rapid tourism growth triggered by recent infrastructure augmentation and investments by the state Govt. The village named Lot no. 126 is located in the southern end of the Jharkhali Island. Thirteen hotels exist in this village out of which twelve are private enterprises, with some major share of local ownership. Households and hotels were primarily surveyed using separate questionnaire and responses were recorded. The major findings of this paper led to the following conclusion:

i. Tourism in Jharkhali Island is growing rapidly as well as profitably, reciprocated with rising tourist foot-fall.

ii. Around $44 \%$ people in Jharkhali Island are directly or indirectly involved with tourism.

iii. Involvement of local community is increasing simultaneously with growth of tourism.

iv. So far, tourism had a positive impact on the economic status of the local people in Jharkhali Island and has received favorable community perception.

v. Community perception on environmental and social impacts of tourism has also been largely in affirmative though a very small section holds negative views.

Overall, it is apparent from the above findings that tourism impact on local socio-economy had been very positive and there is much eagerness in the community for further development of tourism in the region. However, past experiences of unregulated tourism activity in fragile coastal ecosystems have proved counterproductive. Hence it is highly advisable that this growth is guided towards the path of 'ecotourism' in its true sense and be managed sustainably. Exercises such as carrying capacity assessment and strict enforcement of appropriate environmental performances of existing and upcoming hotels are essential to arrest pollution and overconsumption of resource.

\section{REFERENCE:}

[1] Brunt, P. \& Hooton, N. (2010) Community responses to tourism and crime. Article in Crime Prevention and Community Safety, DOI: $10.1057 /$ cpcs.2009.7.

[2] Chaskin, R.J., Brown, P., Venkatesh, S., \& Vidal, A. (2001) Building Community Capacity. New York: Aline De Gruyter.

[3] Cook, R.A., Yale, L.J., \& Marqua, J.J. (2006) Tourism: The Business of Travel. 3rd Edition. New Jersey: Prentice Hall.

[4] Curtis, S.J. (1933) Working plans for the forests of the Sundarbans Division, Bengal, India, for the period from 1931 to 1951.Govt. of West Bengal, Calcutta.

[5] Dalton, H., Elias, J., \& Wandersman, A. (2001) Community psychology: Linking individuals and communities: Stamford. CT: Wadsworth.

[6] Horn, C., Simmons, D.G., \& Fairweather, J.R. (2000) Evolving Community Response to Tourism And Change in Rotorua Tourism Research and Education Centre (TREC), Report No. 14, Lincoln University.

[7] http://shodhganga.inflibnet.ac.in/bitstream/10603/71785/10/10_ch apter\%201\%20introduction.pdf

[8] Imran, Md.M., \& Nguyen, N.T.B. (2018) A Community Response to Tourism, Focusing on the Home-stay Program in K Village in Nainital, Uttarakhand, India. Journal of Urban and Regional Studies on Contemporary India, 4(2): 55-62.

[9] Masud, M.M., Aldakhil, A.M., Nassani, A.A., \& Azam, M.N (2017) Community-based ecotourism management for sustainable development of marine protected areas in Malaysia. Ocean \& Coastal Management 136: 104-112, http://dx.doi.org/10.1016/j.ocecoaman.2016.11.023.

[10] Policy Research Working Paper 7606. World Bank Group (2016) Estimating International Poverty Lines from Comparable National Thresholds.

[11] Rajasenan, D., Manaloor, V., \& Abraham, G.B. (2012) SocioEconomic Aspects of Sustainable Ecotourism Development: The Case Study Kerala. Research on Humanities and Social Sciences, 2 (11).

[12] Sahara and the Sunderbans - Ecotourism or Megatourism?http://indiaresource.org/issues/globalization/2004/s aharasunderbans.html

[13] Sahara to promote eco-tourism in the Sundarbanshttp://timesofindia.indiatimes.com/articleshow/26807 872.cms?utm_source=contentofinterest\&utm_medium=text\&utm _campaign $=$ cppst

[14] Samanta, K., \& Hazra, S. (2012) Landuse / Landcover change study of Jharkhali Island Sundarbans, West Bengal using Remort Sensing and GIS. Inter National Journal of Geomatics and Geosciences, 3 (2)

[15] Singh, R.B., Mal, S., \& Kala, C.P. (2009) Community Responses to Mountain Tourism: A Case in Bhyundar Valley, Indian Himalaya. J. Mt. Sci. 6: 394-404, DOI: 10.1007/s11629-0091054-y. 
[16] Swetnama, R.D., Fisher, B., Mbilinyi, B.P., Munishi, P.K.T., Willcock, S., Ricketts, T., Mwakalila,S., Balmford, A., Burgess, N.D., Marshall, A.R., \& Lewis, S.L. (2011) Mapping socioeconomic scenarios of land cover change: A GIS method to enableecosystem service modeling. Journal of Environmental Management, 563-574, doi:10.1016/j.jenvman.2010.09.007.

[17] Telfer, D.J., \& Sharpley, R. (2008) Tourism and Development in the Developing World. Abingdon (Oxon) and New York:Routledge.

[18] Wall, G. \& Mathieson, A. (2006) Tourism: Change, Impacts and Opportunities. England: Prentice Hall.

[19] WWF. Indian Sundarbans Delta : A Vision (2011). Available: http://awsassets.wwfindia.org/downloads/indian_sundarbans_delt a_a_vision.pdf. 